\title{
Os efeitos do encarceramento feminino para a família da mulher presa: aspectos da transcendência da pena
}

\section{The effects of female incarceration on the female prisoner's families}

\section{Mariana Paganote Dornellas}

Mestra em Ciências Jurídicas e Sociais pela Universidade Federal Fluminense com bolsa CAPES. Bacharela em Direito pela Universidade Federal Fluminense. Integrante do Conselho Administrativo da Associação Elas Existem - Mulheres Encarceradas. ID ORCID: https://orcid.org/0000-0003-29371916.

\section{Resumo}

O presente trabalho tem por objetivo investigar os impactos do encarceramento na família de mulheres presas, abordando aspectos relacionados ao estigma e às diversas formas de mortificação do eu a que seus visitantes são submetidos durante o procedimento de visita, evidenciando as condições derivadas da prisionização secundária, além das repercussões para seus filhos. Esta é uma apresentação dos dados coletados por meio de pesquisa empírica qualitativa realizada com os visitantes das mulheres encarceradas na Penitenciária Talavera Bruce, em que analisamos de que forma e em que medida as consequências do encarceramento se estendem para a família de tais pessoas.

Palavras-chave: Encarceramento Feminino, Família da Pessoa Presa, Transcendência da Pena, Estigma, Mortificação do Eu.

\section{Abstract}

This paper's objective is to investigate the impact of incarceration on female prisoners' families. We will address aspects related to stigma, and the various forms of mortification of self to which the visitors of the prisoners are subjected during the visitation procedure, evidencing the conditions of secondary prisonization, as well as the effects on arrested women's children. This is a presentation of the data collected through qualitative empirical research carried out with the visitors of the women imprisoned in Talavera Bruce Penitentiary, in which we analyze how and how much the consequences of imprisonment extend to the female prisoner's families.

Keywords: Female Imprisonment, Arrested Person's Family, Transcendence of the Penalty, Stigma, Mortification of Self. 


\section{INTRODUÇÃO}

O princípio da intranscendência da pena, disposto no art. $5^{\circ}, \mathrm{XLV}$, da nossa Constituição, indica que nenhuma pena passará da pessoa do condenado. Assim, deve-se evitar que as consequências da punição afetem terceiros, pois esta é uma medida de caráter estritamente pessoal (ZAFFARONI; PIERANGELI 2011, p. 160). Porém, sabemos que, na realidade, a pena privativa de liberdade tem impacto especialmente na família da pessoa encarcerada. Quando tratamos do encarceramento feminino, a questão é mais complexa, dado que as mulheres ainda são as principais responsáveis pelas tarefas ligadas à esfera reprodutiva da vida social, sejam afazeres domésticos ou de cuidado de crianças, idosos e pessoas doentes em geral, mesmo que também exerçam trabalho remunerado.

Neste texto apresentamos parte do material de pesquisa empírica qualitativa desenvolvida para a elaboração de dissertação de mestrado, realizada por meio de entrevistas semiestruturadas com os visitantes das mulheres presas na Penitenciária Talavera Bruce, com o objetivo de estabelecer quais são os impactos do encarceramento para suas famílias. Temos consciência de que, entrevistando as pessoas que visitam suas familiares presas, podemos oferecer apenas uma análise parcial de como o encarceramento da mulher atinge a família, tendo em vista que a maior parte destas não recebe visitas regulares.

\section{METODOLOGIA}

A Penitenciária Talavera Bruce foi escolhida como local da realização da pesquisa porque atualmente é destinada às mulheres já condenadas. Logo, é possível supor que ali as mulheres se encontram presas há mais tempo do que aquelas que ainda não foram julgadas. Portanto, os impactos na família são mais mensuráveis. Ademais, a Penitenciária Talavera Bruce possui uma entrada distinta das unidades prisionais que integram o Complexo Penitenciário de Gericinó, permitindo assim o contato somente com os visitantes de presas mulheres. 
A abordagem dos entrevistados se deu durante a espera para a visita, que ocorre às quartas-feiras, sábados e domingos, com entrada entre $9 \mathrm{~h}$ e $12 \mathrm{~h}$ e saída às $16 \mathrm{~h}$. Foram realizadas seis visitas nos meses de julho e agosto de 2017, com entrevistas feitas a 41 pessoas. Algumas duraram apenas dez minutos, outras, mais de quarenta minutos. Todos os diálogos foram gravados com a anuência dos interlocutores, e transcritos integralmente. A seleção dos visitantes para entrevista buscou abarcar pessoas das mais variadas faixas etárias, raças, gêneros, classes e orientações sexuais, para que houvesse diversidade nas experiências. Para preservar o anonimato dos interlocutores foi suprimida especificação de nomes ou de outras características que permitissem identificá-los, ou qualquer um de seus familiares, como local de residência ou trabalho, sendo seus relatos indicados pelo dia e ordem das entrevistas.

Das 41 pessoas entrevistadas, apenas nove eram homens. Destes, três visitavam a esposa; dois encontravam a filha; outros dois, a mãe; um, a irmã; e um visitava a cunhada. Dentre as mulheres, 14 visitavam a filha; oito encontravam a mãe; quatro, a irmã; três, a sobrinha; duas, a companheira; e uma visitava a tia. Podemos perceber que os homens visitam menos, tanto em penitenciárias femininas quanto nas masculinas. Isso acontece porque as mulheres são socializadas para exercer o cuidado, para se responsabilizar por todas as pessoas vulneráveis da família, sejam crianças, idosos ou doentes. Isso implica que, em caso de encarceramento, as esposas, mães, filhas e irmãs das pessoas presas se comprometam mais em manter o vínculo familiar e contribuir para suprir suas necessidades do que seus correspondentes masculinos. Das 41 pessoas entrevistadas, 17 indicaram serem as únicas visitantes da mulher presa.

Inicialmente, a autoidentificação étnico-racial não estava prevista no roteiro, mas, no decorrer da pesquisa, percebemos que esse era um dado indispensável para a compreensão da realidade. Assim, tendo em vista a impossibilidade de indagar os entrevistados a respeito dessa questão, pois boa parte das interlocuções já tinha sido realizada, não tivemos escolha a não ser coletar esses dados a partir da heteroatribuição da entrevistadora (IBGE, 2013, p. 44), baseada exclusivamente em características fenotípicas. Essa análise se mostrou fundamental, pois, ainda que não tenham sido perguntados diretamente sobre discriminação racial, a distinção de tratamento a partir das características étnico-raciais dos entrevistados surgiu espontaneamente, e não 
poderia deixar de ser incluída na pesquisa. Utilizou-se o sistema de classificação do IBGE, com cinco categorias: branco, pardo, preto, amarelo e indígena (IBGE, 2013, p. 24), sendo que não se constatou haver pessoas pertencentes aos dois últimos grupos.

Dos entrevistados, 14 foram identificados como brancos; 13, como pretos; nove, como pardos. Não possuímos informação sobre cinco pessoas. Observamos que a população negra está sobrerrepresentada entre os visitantes de mulheres presas, reflexo da sobrerrepresentação da população negra no cárcere, principalmente em relação às mulheres. De acordo com o Levantamento Nacional de Informações Penitenciárias, $62 \%$ da população prisional feminina é negra (DEPEN, 2018, p. 40). Em alguns estados, quase a totalidade das mulheres presas são negras, como Acre (97\%), Ceará (94\%), Maranhão (90\%), Piauí (90\%) e Tocantins (90\%). No Rio de Janeiro, onde a pesquisa empírica foi realizada, $65 \%$ das mulheres encarceradas são negras. Na medida em que todos os entrevistados eram familiares da mulher presa, ainda que parte de sua família extensa, pressupõe-se um compartilhamento, mesmo que não integral, de suas características fenotípicas, o que explica a maior incidência de pessoas negras entre os visitantes.

Os entrevistados residem em bairros diversos da cidade do Rio de Janeiro, como Bangu, Freguesia, Campo Grande, Cidade de Deus, Mangueira, Senador Camará, Taquara, Bonsucesso, Copacabana, Acari, Penha, Realengo e Praça Seca. Há até mesmo quem more em outras cidades do estado, como Angra dos Reis, Alcântara, Petrópolis, Cachoeiras de Macacu, Belford Roxo, São Gonçalo, São João de Meriti, Resende, Barra Mansa, Duque de Caxias, Niterói, Queimados, Paraíba do Sul, Volta Redonda, Cabo Frio e Mangaratiba. Um residia no estado de São Paulo. Observa-se assim a prevalência de visitantes de áreas de periferia das cidades do Rio de Janeiro e da Baixada Fluminense, regiões conhecidas pela vulnerabilidade social dos moradores e pela constante atuação violenta da polícia.

A concentração de presídios na cidade do Rio de Janeiro, principalmente no Complexo Penitenciário de Gericinó, que conta com 22 unidades prisionais, prejudica a comunicação com a família, essencial para a futura reintegração social da pessoa presa. Essa questão é ainda mais difícil para as mulheres encarceradas, visto que existem apenas seis penitenciárias femininas no estado e, destas, apenas uma fica fora da cidade do Rio de Janeiro, em 
Campos dos Goytacazes. Essa concentração faz com que mulheres de todo o estado fiquem presas em Bangu, na Zona Oeste da capital, tornando as visitas muito custosas e desgastantes, visto que os familiares precisam sair de casa ainda de madrugada, ou até mesmo na noite anterior, para conseguir chegar no horário para realizar a visitação, enfrentando um custo altíssimo de transporte, agravado quando levam crianças consigo e, portanto, devem pagar mais de uma passagem. Ainda que alguns possuam veículo próprio, o que facilita a locomoção, a distância é um problema: agrega-se à despesa de levar os itens necessários para a subsistência da presa o custo do transporte, além de toda a logística necessária para realizar grandes deslocamentos.

Assim, quando tratamos das famílias afetadas pelo encarceramento de mulheres, cabe destacar que são pessoas com um perfil bem delimitado quanto a gênero, raça e localização geográfica, e que os impactos do encarceramento feminino não se distribuem de forma homogênea na sociedade, pelo contrário, atingem com mais intensidade as mulheres negras moradoras de periferia, agravando sua situação de vulnerabilidade social.

\section{ESTIGMA}

Um dos aspectos que se destacou dentre os efeitos da prisão para a família da mulher encarcerada foi o estigma associado ao crime e, logo, à prisão. Este se estende aos familiares e faz com que os mesmos sintam a necessidade de esconder ter ocorrido a prisão de pessoas próximas, para se preservarem.

5.3 "E realmente a situação é muito difícil, e eu sofro discriminação até com a minha família. É, porque eu venho visitar, eles falam comigo: 'Você tá livre, cara'. E eu não tô livre, não, eu tenho um casamento, eu tenho um contrato diante de Deus e diante do homem, né, e eu prezo, eu honro essa parte com ela, porque eu acho que é justo, mais do que justo, né?"

5.5 "É muito difícil pra mim, pra minha família, meu irmão sofreu bullying na escola, teve que trocar de escola, minha filha também, no meu trabalho meu patrão graças a Deus sabe da minha situação, quando ele me empregou eu conversei, e pra mim foi um choque, não é que eu não aceito, mas eu vou fazer o quê?" 
6.4 "A pior parte é [...] é mais psicológico mesmo, é muito ruim, porque você perde um dia, né, até porque eu perco um dia de trabalho, eu tenho que dar uma informação diferente no local de serviço, porque você falar a realidade, o que é, você pode até perder o emprego, porque o patrão não quer saber, vai achar que por você ser parente de alguém que está preso você pode ser uma má influência na empresa, né, e eles mandam embora mesmo."

6.2 "Foi muito ruim, porque de algumas pessoas eu tive que esconder, como escondi até hoje, e eu fico muito sozinha, né?"

6.3 "Ah, sim, minha filha na escola, as pessoas, teve famílias que proibiram minha filha de ficar junto, porque ela apareceu na televisão, no próprio lugar onde eu morava, eu tive que me mudar, porque as pessoas pararam de falar comigo, no meu emprego, no meu emprego agora ninguém sabe que eu visito, porque no outro eles descobriram e eu tive que pedir as contas. Porque falaram que quando ela ia sair ela poderia roubar onde eu trabalhava. Eu não tenho nada a ver com isso."

A partir dos relatos, podemos perceber como o estigma ligado ao encarceramento afeta os familiares da mulher presa em diversos âmbitos: na escola, no trabalho, no local de residência e até mesmo na própria família. Desse modo, as pessoas buscam ocultar a situação para tentarem levar uma vida não marcada, pois a força dessa informação é tão grande que, quando descoberta, os familiares se veem diante da necessidade de mudar as crianças de escola, trocar de emprego ou de residência. Verifica-se, assim, uma transmissão do estigma.

Goffman (1981), ao tratar desse tema, aborda também a conexão que aqueles que estão próximo da pessoa estigmatizada mantêm com o estigma. Ele identifica como pessoa "informada" o indivíduo que se relaciona com alguém estigmatizado através da estrutura social, em um envolvimento que leva a sociedade mais ampla a considerar ambos como uma só pessoa, citando, como exemplo, entre outros, a família de quem está preso. Ele afirma que essas pessoas são obrigadas a compartilhar um pouco do descrédito dirigido ao estigmatizado, pois os problemas que este enfrenta espalham-se em ondas de intensidade decrescente (GOFFMAN, 1981, p. 28-29). O indivíduo que tem um estigma de cortesia pode sofrer com a maior parte das privações típicas do grupo que assumiu e, ainda assim, não desfruta da autoexaltação, a defesa comum frente a tal tratamento (GOFFMAN, 1981, p. 30). 
Dessa forma, em decorrência da possível difusão de um estigma, as relações mais próximas do indivíduo tendem a ser evitadas ou a terminar, caso já existam (GOFFMAN, 1981, p. 29). Na ausência do intercâmbio social quotidiano com os outros, o estigmatizado que se autoisola tende a se tornar desconfiado, deprimido, hostil, ansioso e confuso (GOFFMAN, 1981, p. 14), como muitos visitantes relataram. Até mesmo o estabelecimento de vínculo com outros visitantes é prejudicado, visto que há certa ambivalência quando o indivíduo compreende pela primeira vez quem são as pessoas que de agora em diante ele deve aceitar como seus iguais, porque ele as encara como nitidamente estigmatizadas e, portanto, diferentes da pessoa normal que ele acredita ser. Também porque aquelas podem deter outros atributos que, para ele, dificilmente são associados ao seu caso (GOFFMAN, 1981, p. 34).

O autor diz que, quando uma pessoa possui um defeito secreto desacreditável, há um grande esforço para seu encobrimento por meio do controle de informação, na tentativa de se poupar dos efeitos do estigma, como podemos observar pela necessidade de mudança de residência, escola e até mesmo de trabalho. A questão torna-se ainda mais difícil quando aqueles para quem o indivíduo estigmatizado não se revelou são pessoas próximas, e o temor da descoberta prejudica não só a situação social corrente, mas as relações sociais estabelecidas e as que virão no futuro (GOFFMAN, 1981, p. 58). Segundo Goffman (1981), o indivíduo que se encobre sofre de "aprofundamento de pressão", constrangido a elaborar mentiras continuamente para evitar uma revelação, as quais podem, elas próprias, ferir sentimentos e dar lugar a mal-entendidos (GOFFMAN, 1981, p. 73).

Além disso, ao tentar manter o estigma em segredo, haverá o sentimento de culpa, por não se abrir perante uma pessoa íntima (GOFFMAN, 1981, p. 65). Há um impacto relevante no estado psíquico de quem se encobre, pois um alto preço psicológico é pago: a pessoa permanece em um nível muito elevado de ansiedade, por levar uma vida que pode entrar em colapso a qualquer momento (GOFFMAN, 1981, p.76). Então, o estigma e o esforço para escondê-lo tornam-se parte de sua identidade pessoal (GOFFMAN, 1981, p. 58). As pessoas que tentam ocultar um estigma, como os visitantes que se esforçam para esconder a situação de encarceramento de um familiar, têm a constante necessidade de manipular informação, o que gera tensão e um 
sentimento de culpa por mentir. Isso faz com que a pessoa se isole, agravando ainda mais as consequências para a sua vida.

Comfort (2008) afirma que, como o visitante tem uma ligação pessoal com o indivíduo preso (em geral é parte de sua família), o tratamento recebido durante a revista é completamente diferente daquele dado a outras pessoas que entram nas penitenciárias, como quem faz trabalho voluntário, por exemplo. O relacionamento com a pessoa presa torna o visitante objeto de desconfiança, sendo identificado como potencialmente ameaçador e, portanto, merecedor de recriminação, pelo compartilhamento do estigma. Por isso, os agentes penitenciários promovem diversas formas de privações e degradações aos visitantes, conectando a sua experiência no sistema prisional com aquela vivenciada pelo seu familiar encarcerado, e diluindo a distinção entre quem é um "preso" e quem não é (COMFORT, 2008, p. 63).

Assim, a autora sustenta que os visitantes ocupam uma posição curiosa em relação à prisão, pois não são totalmente prisioneiros nem totalmente livres, e precisam fazer malabarismos com automodificação e autopreservação para penetrar na fronteira carcerária. Ao mesmo tempo em que conseguem entrar e manter os laços com a pessoa querida que se encontra presa, inconscientemente preparam a base para uma distorção de longo prazo causada pela instituição em seus mundos pessoal, doméstico e social (COMFORT, 2008, p. 64).

No mesmo sentido, Braman (2002) indica que o estigma da criminalidade associado ao encarceramento marca tanto a pessoa quanto seus familiares (BRAMAN, 2002, p. 133), e que a consequência mais significativa do estigma para estes últimos é a distorção, diminuição e até mesmo rompimento dos laços sociais (BRAMAN, 2002, p. 131). Muitas pessoas passam a evitar a família e os amigos, para não terem que mentir em relação ao encarceramento. Por outro lado, os próprios amigos e familiares podem começar a se distanciar daqueles que realizam a visitação a uma pessoa encarcerada, para se esquivarem de ter que contribuir de alguma forma, seja visitando também ou fornecendo auxílio financeiro (BRAMAN, 2002, p. 121).

$\mathrm{O}$ autor afirma que os desdobramentos podem ser até mesmo maiores para a família do que para a pessoa efetivamente encarcerada, visto que estigma e vergonha são experimentados em relação à percepção e julgamento de outros membros de um determinado grupo social. Enquanto os presos 
mantêm relações entre si, com menor influência do estigma, os familiares permanecem em suas comunidades e estão sujeitos a diversos tipos de pressão social, seja dos vizinhos, da igreja ou dos companheiros de trabalho (BRAMAN, 2002, p. 133). Por essa razão, Braman (2002) explica que, embora os legisladores possam considerar a vergonha uma sanção adequada para aqueles que cometem um crime, o estigma relacionado ao encarceramento é frequentemente suportado pelos familiares das pessoas presas, que não cometeram nenhum delito (BRAMAN, 2002, p. 134).

A estigmatização ligada ao cárcere se estende aos familiares da pessoa presa, que sofrem seus efeitos não apenas em relação à comunidade na qual estão inseridos, principalmente por meio do isolamento e das consequências da ocultação para evitar o estigma, mas também nas suas incursões no ambiente prisional por ocasião das visitas, algo evidente diante do tratamento diferenciado que lhes é dispensado pelos agentes penitenciários, o que será analisado a seguir.

\section{FORMAS DE MORTIFICAÇÃO DO EU}

Goffman (1961, p.11) define instituição total como "um local de residência e trabalho onde um grande número de indivíduos com situação semelhante, separados da sociedade mais ampla por considerável período de tempo, leva uma vida fechada e formalmente administrada", da qual seriam exemplos os manicômios, as prisões e os conventos. Ao descrever o processo de mortificação do eu em uma instituição total, o autor explica que, quando chega ao estabelecimento, o novato é despido das concepções de si mesmo criadas com base de algumas disposições sociais estáveis em seu mundo doméstico. A partir de sua entrada, ele tem seu eu sistematicamente mortificado, ainda que de forma não intencional, a partir de uma série de rebaixamentos, degradações, humilhações e profanações, que produzem mudanças radicais em sua carreira moral, ou seja, nas crenças que tem a respeito de si mesmo e dos outros que são significativos para ele (GOFFMAN, 1961, p. 24).

Assim, a mortificação do eu seria o resultado do processo por meio do qual a pessoa abandona a sua anterior concepção de si mesmo ao entrar na instituição total, o que ocorre durante o processo de adaptação à rotina total- 
mente administrada por terceiros. Embora não estejam internados, podemos observar algumas formas de mortificação do eu similares às descritas pelo autor às quais são submetidos os familiares que visitam as mulheres encarceradas, ainda que apenas no curto período de tempo em que ocorrem esses encontros. Parece-nos que entrar em contato com o ambiente carcerário, devido à relação com a pessoa encarcerada, faz com que muitos dos comportamentos exigidos das presas sejam também impostos a seus familiares, que são tratados de forma equivalente.

\section{DESFIGURAÇÃO PESSOAL}

Por exemplo, Goffman (1961) descreve que, na admissão em uma instituição total, normalmente o indivíduo é despido de sua aparência usual, o que provoca sua desfiguração pessoal (GOFFMAN, 1961, p. 28). Os visitantes, por sua vez, indicam que precisam ir de "uniforme" para o presídio. Em função das diversas restrições de roupas relativas a cores, modelos e tipo de calçado e do risco de serem impedidos de entrar, ou de serem levados ao scanner, que fica fora da unidade prisional, reduzindo assim o tempo da visita, os familiares se habituam a ir sempre com a mesma roupa, dentro dos padrões estabelecidos, para evitar problemas.

Observa-se a redução da autonomia dos visitantes para determinar sua aparência: estes não podem ir ao presídio com roupas nas cores preta, branca, azul, verde, amarela ou vermelha. Devem preferir roupas estampadas, o que pode ser uma dificuldade, principalmente no que diz respeito a agasalhos para os dias frios. Ademais, só entram de chinelos, independente de o tempo estar frio ou chuvoso. É preciso evitar roupas com botões e zíperes, como calças jeans e jaquetas, pois fazem soar o detector de metais, o que faz com que sejam encaminhadas ao scanner do Complexo de Gericinó. Também não podem entrar no local com qualquer tipo de acessório, como aliança, brincos, cordões e cintos. ${ }^{1}$

\footnotetext{
É interessante notar que Comfort (2008) esteve no Complexo Penitenciário de Gericinó em outubro de 2001, realizando pesquisa de campo, e na ocasião relatou não haver um código de vestimenta para os visitantes de prisões no Brasil. A autora identificou como uma consequência do reconhecimento da pobreza dessas pessoas (COMFORT, 2008, p. 60).
} 
3.1 "O meu uniforme é esse, eu entro, eu não dou dor de cabeça [...]. Tem roupa que apita, tem roupa que não apita, tem roupa que não pode, tem cor também. Então eu boto essa roupa aqui porque sei que é a roupa minha padrão, se um dia eu passar no scanner e ela ficar apitando é porque tá fora do padrão alguma coisa, porque essa roupa não apita. A mesma calça e duas camisas diferentes, já sabe que esse é o caminho, até terminar essa luta. Vermelho não pode, por causa da facção, preto não pode, tem umas cores que não pode devido à facção, essas coisas existem no sistema prisional, não tem jeito, temos que acatar e respeitar isso."

3.4 "Não pode branco, não pode verde, não pode azul, não pode preto, não pode vermelho, cores coloridas assim, misturado você pode entrar, mas essas cores não pode, porque a cantina lá dentro é amarela, aí as funcionárias que ficam trabalhando, que são as presas que ficam varrendo, essas coisas assim, as roupas delas são verdes, as policiais, no caso, a roupa delas são azul marinho, aí você não pode entrar por causa disso, por causa da norma lá mesmo, pra não confundir."

As entrevistas aconteceram nos meses de julho e agosto, durante o inverno, portanto. Embora o Rio de Janeiro não seja conhecido por invernos rigorosos, o contraste do curto período de frio com a maior parte do ano, em que há muito calor, faz com que as pessoas não possuam grande variedade de agasalhos, principalmente as mais pobres. Em um dia de temperaturas particularmente mais baixas, em que chovia, presenciamos algumas pessoas apenas de camisa, que se encolhiam de frio. Conversando com uma delas, soubemos que trabalhava como segurança em eventos, e que seus casacos eram pretos, por isso não poderiam ser usados. Ela preferia ficar com frio do lado de fora do que esperar com o casaco e ter que jogá-lo fora na hora de entrar, porque não há um local para armazenamento dos itens proibidos. Um homem que participava da conversa nos disse que alugou um casaco em um estabelecimento próximo por $\mathrm{R} \$ 10$.

Como é difícil encontrar agasalhos nas especificações do sistema prisional e que, de qualquer forma, tal incidiria em um gasto adicional, a maior parte das pessoas não tem alternativa a não ser ficar por horas esperando no frio, que se potencializa com os pés molhados, visto que só é possível entrar de chinelos de dedo. Principalmente as crianças e os idosos ficam expostos a doenças, que podem evoluir para uma pneumonia, por exemplo. A própria 
restrição de calçados nos parece uma forma de diferenciar os visitantes de outras pessoas que circulam no ambiente penitenciário, demonstrando que, de alguma forma, são considerados inferiores e indignos, sendo desprezados, assim como as pessoas presas, conforme descrito no relato a seguir:

6.2 "Eu não sei, não me informaram, não, porque quando eu vim, vim até de sapato, de tênis, não deixaram nem eu nem minha irmã especial entrar, a gente não sabia, e como eu estava sem dinheiro, nós não podia alugar, fomos embora, né, aí eu perguntei a ele se podia deixar a comida, 'Não, a senhora vai embora junto com a comida', nem a sucata entrou, não pode, o lance do sapato deve ser porque muitas pessoas fazem coisas erradas, traz chip, essas coisas assim, não sei, eu acho também que não seja por isso não, acho que é porque não pode mesmo, só quem pode andar arrumado é eles, é uma forma de identificar, de humilhação, pra mim é uma humilhação, que a gente vem pra um lugar assim, né? [...] A gente aluga roupa, se eles implicar com a roupa da gente, assim, eu tô vindo com essa saia aqui florida, é meu uniforme, aí eu tiro a blusa e fico com essa daqui. Sempre com a mesma roupa pra não ter problema, porque às vezes a gente não tem dinheiro pra alugar, hoje mesmo eu vim pura, vim só com dez reais pra deixar com a minha filha, caso ela precise, né?"

Um item que notamos ser capaz de trazer problemas com frequência, analisado também por Comfort (2008), são os sutiãs, pois um número considerável possui uma armação de metal em seu bojo, o que aciona o detector. Em San Quentin, penitenciária em que ocorreu a pesquisa da autora, as visitantes são orientadas a retirar a armação metálica, deformando a peça mas possibilitando sua entrada com ela (COMFORT, 2008, p.54). Na Penitenciária Talavera Bruce, por outro lado, as mulheres são levadas a escolher entre jogar o sutiã fora ou não realizar a visita, porque, ao contrário da penitenciária estadunidense, não possui armários para que sejam guardados os itens proibidos. Essa restrição causa embaraço, em razão da natureza íntima do objeto e porque podem ser submetidas a esse tipo de controle por um agente penitenciário homem (COMFORT, 2008, p. 54). Há também o constrangimento de ter que descartar um bem pessoal, reforçando o sentimento de impotência e sujeição diante do sistema penitenciário, independente da sua situação econômica ou cultural do lado de fora (COMFORT, 2008, p. 59). 
5.2 "A outra me chamou lá quando eu passei no scanner, me chamou lá e falou: 'Esse sutiã não pode, o que a senhora vai preferir? Visitar, [porque] se [for] visitar tem que jogar fora, ou deixar de visitar?' Aí eu falei, 'Não, vou visitar', então joguei o sutiã fora pra poder entrar. [...] Tive que jogar fora, porque eu não podia sair mais, depois que entra não pode mais sair pra poder deixar nada."

As violações do código de vestimenta e portar alimentos considerados proibidos são os impasses mais comuns enfrentados por visitantes. Isso acontece porque estes não são avisados com antecedência sobre as restrições impostas. Especificações sobre os trajes incluem diversas proibições relativas a cores, tecidos e acessórios, as quais são ainda mais problemáticas para pessoas sem condições de renovar seu guarda-roupa, para que este se adapte à prisão (COMFORT, 2008, p.52). Com a frequência das visitas, aprende-se que os códigos de vestimenta e de alimentos permitidos não apenas mudam frequentemente e de forma imprevisível como são aplicados de forma irregular, a depender do agente penitenciário de plantão naquele dia e de seu estado de humor (COMFORT, 2008, p. 54). Isso faz com que se tenha permissão para entrar na unidade com determinada roupa e alimentos em um dia e que, em outra oportunidade, esse mesmo item seja rejeitado.

Mesmo para os visitantes regulares é uma zona de incerteza, de um momento para outro pode haver mudanças no código de vestimenta, nos alimentos permitidos ou em sua forma de acondicionamento, das quais as pessoas só irão tomar conhecimento no momento da revista, sem nenhuma comunicação prévia, nem mesmo um aviso afixado ao portão. Assim, cada visita é uma surpresa. Há sempre uma tensão sobre a permissão de entrada e com o que será viável fazê-lo. Essa instabilidade e ausência de informação clara sobre o que é permitido ou não faz com que as pessoas se sintam desvalorizadas e impotentes diante de situações que influenciam diretamente as suas vidas mas que não podem prever ou para as quais não conseguem se preparar adequadamente (COMFORT, 2008, p. 47).

\section{EXPOSIÇÃO CONTAMINADORA}

Goffman (1961) indica, ainda, outra forma de mortificação do eu, a exposição contaminadora. Ele explica que, no mundo externo, o indivíduo 
pode manter os objetos ligados aos sentimentos do eu (como seu corpo, seus pensamentos e alguns de seus bens) fora de contato com coisas estranhas e contaminadoras. Contudo, nas instituições totais, a fronteira que o indivíduo estabelece entre seu ser e o ambiente é invadida, e esses territórios do eu são violados (GOFFMAN, 1961, p. 31).

O autor informa que o tipo mais evidente de exposição contaminadora é o físico, relacionado à sujeira (GOFFMAN, 1961, p. 32). Os visitantes se queixam com frequência do espaço em que aguardam a visitação ficar coberto de lixo, acumulado por semanas, o que provoca mau odor e atrai animais. Ainda, há o desconforto em ser considerado alguém que deve suportar a presença de detritos, como se eles próprios fossem considerados lixo também.

1.5 "É humilhante a gente ter que esperar, né, mediante de tanto lixo, com criança, né, mas eu não sei. Porque realmente lá dentro não é assim. Lá dentro você não vê, entre elas mesmo, elas têm que manter limpo. A minha irmã mesmo, não sei se foi benefício que ela ganhou, mas ela trabalha em voluntária, não recebe, né, então ela tem que manter os corredores limpos e aqui fora é essa tristeza. É horrível. Você já sai daqui com essa imagem. Eu tenho até pesadelo às vezes, no meio da noite, de sonhar com uma coisa horrível dessa. Ficar esperando, num lugar tão feio assim. É horrível isso. É muito... Parece que o ser humano, acabou mesmo o amor entre as pessoas."

2.3 "Visita aqui é isso que você tá vendo. Olha o lixo. Olha pra isso. A gente convive com isso aqui todos os dias de visita. Quando isso aqui é varrido, somos nós que varremos. A gente pede uma vassoura e varre. Fica esse chiqueiro aqui. Hoje, tudo bem. Dia de calor, barata fica rodando aqui. Lá dentro tem urubu. Um cheiro de podre, de chiqueiro que tinha. Agora não sei, acho que acabaram com o porco, não sei. Um cheiro horrível. Em resumo: é um submundo. Só quem entra e frequenta como a gente. Elas não podem falar. Estão presas. Estão pagando o pecado, o erro. Estão pagando. Mas é sub-humano. Diz que é pra ressocializar. Mentira. Saem piores. A revolta é muito grande."

Comfort (2008) assegura que existem diversos elementos pequenos, porém significativos, que indicam que o bem-estar dos clientes não é levado em consideração pelos funcionários, como por exemplo, a ausência de um local adequado para espera, suficientemente limpo, com assentos confortáveis, um bebedouro em funcionamento e um banheiro com fraldário (COMFORT, 
2008, p. 45-46) - exatamente a situação em que se encontram os visitantes da Penitenciária Talavera Bruce, que devem aguardar por muitas horas em um local cheio de lixo, com um número insuficiente de assentos, sem acesso à água potável ou banheiro.

Um exemplo dramático de contaminação interpessoal utilizado por Goffman (1961) é a revista por meio de exame retal, em que tanto o examinador quanto o exame penetram a intimidade do indivíduo e violam o território de seu eu (GOFFMAN, 1961, p. 35). Para os visitantes, as lembranças da revista íntima ilustram bem a violação desse tipo a que eram submetidos.

A revista íntima vexatória foi proibida nas unidades prisionais do estado do Rio de Janeiro após acordo judicial realizado entre a Defensoria Pública e o governo do estado, homologado em setembro de 2017. O documento tornou definitiva a decisão obtida em segunda instância pela Defensoria Pública no Agravo de Instrumento no 0008637-13.2015.8.19.0000, em abril de 2015. Essa decisão foi fundamentada na desnecessidade da medida e no princípio da intranscendência da pena, bem como no repúdio ao tratamento desumano e degradante que implicava, afrontando gravemente a Constituição brasileira.

Braman (2002) afirma que os familiares sofrem diversas indignidades descabidas durante a visitação, como a recusa injustificada de entrada, sendo as mais graves a revista íntima e os insultos a que são frequentemente submetidos (BRAMAN, 2002, p. 120). Os visitantes relatam que deviam ficar nus para a revista, que consistia em agachar diante do agente penitenciário por diversas vezes, às vezes em cima de um banco ou sobre um espelho, e soprar em uma garrafa, entre outros procedimentos invasivos e completamente humilhantes.

1.7 "Quem fez alguma coisa foi eles. Não tem que ser a gente que teria que passar por revista íntima. E é uma coisa superconstrangedora. Eu lembro da minha primeira vez como se fosse hoje. A primeira vez a gente nunca esquece [risos]. Então, na minha primeira vez, o rapaz mandou eu tirar a roupa, eu tirei a blusa, o short, fiquei de cueca. Ele olhou pra mim e falou: 'Nu, do jeito que veio ao mundo. Você não sabe o que é nu? Tirar a roupa?' Bem rude, bem grosso. Bem sério. Então eu tirei a cueca e fiquei olhando pra ele e ele disse: 'Agacha'. Nada de "por favor". Ele simplesmente manda e você tem que obedecer. Eu me agachei e ele falou: 'Vira pra mim agora e agacha'. Eu agachei um pouco e ele perguntou se eu tinha problema no joelho, eu falei que não e ele falou: 'Então por que que você não se agacha até 
embaixo?'. Aquilo dali é um constrangimento fora de série. Eu virado pra ele me agachei, tive que virar pra trás e perguntar se tava tudo bem. Tu imagina a cena. Um homem, virado pra outro homem, com as suas partes íntimas de fora, e tu vira pra ele e pergunta se tá bom daquele jeito. Só falta ele manda tu piscar o seu olho virado pra ele. Então é um constrangimento muito grande. A minha mãe fala que o de mulher é pior ainda. Minha mãe fala que de mulher, mandava subir num banquinho de três degraus, tinha que ficar 60 centímetros acima do chão, a mulher se sentava, ou se agachava, e ela mandava tu, simplesmente nua, se agachar e abrir as pernas. Minha mãe falou que a mulher só faltava enfiar o dedo dentro das suas coisas pra ver se você tava carregando, portando alguma droga, e era um agacha e levanta, agacha e levanta."

3.4 "Graças a Deus a revista agora é bem mais tranquila, porque há muitos anos atrás era horrível, eu peguei essa fase porque meu irmão também foi da pá virada, eu tinha que tirar a roupa, me abaixar, me arreganhar toda, botava um espelhinho no chão pra você fazer, agora graças a Deus acabou com isso, agora é pelo scanner."

6.3 "Era bem pior, tinha que tirar a roupa, tinha que agachar, tinha que assoprar na garrafa, pelada, agora melhorou bastante. É o que eu falo, a gente tem que se acostumar, porque é o que a gente está vivendo, se não tivesse a revista íntima eu não podia entrar, e eu tinha que vê-la, então... A gente agora é igual ela, um número no sistema, tem que se acostumar conforme eles querem."

Assim, podemos perceber que os visitantes eram submetidos a diversas formas de humilhação desnecessárias por ocasião da revista íntima, e nem mesmo as crianças eram poupadas de tal procedimento, pois há relatos de que os bebês tinham suas fraldas abertas para verificar se não havia nenhuma droga escondida, e que em algumas ocasiões os agentes questionavam os pequenos se estes estavam escondendo alguma coisa, até mesmo sob a ameaça de prendê-los caso descobrissem algo, prática absolutamente inadmissível e desumana.

Os visitantes relatam a humilhação que sentem em todo o procedimento de revista, inclusive dos alimentos, e especialmente por ter que acondicionar a comida em sacos plásticos, seja para o consumo junto com a presa no almoço, caso a quantidade exceda os três potes permitidos, seja para deixar pra a mulher presa como "sucata”. A preparação dos itens para a entrada no presídio é trabalhosa, custosa e demanda tempo dos visitantes, devido a todas as es- 
pecificações da penitenciária sobre como acondicionar os bens (COMFORT, 2008, p. 80) trazidos para compensar as deficiências da unidade prisional.

3.7 "É humilhante, é humilhante demais, é humilhante demais, que a gente bota no saco transparente, depois bota numa bolsa do Guanabara, e as coisas ficam no chão ali dentro, tem um cachorro ali dentro cheio de pulga, entendeu, carrapato, que já encontraram, e as bolsas ficam tudo ali naquele chão, tudo no chão ali como se fosse bicho aí dentro, fica tudo no chão, as comidas que vai da visita bota no alto assim, e as outras, que é a sucata, que dá o nome de sucata, fica no chão ali, quer dizer, eu acho que a pessoa já está aí pagando pelo erro, acho que não precisa também tanta humilhação, né? Como a comida para a visita é três potes só [...], aí tive que trazer uma salada de legumes dentro de um saco, nossa, aí botei no prato e me senti um lixo, sabe, tirando a comida de dentro do saco, porque eu tinha trago um pote de macarronese, trouxe outro com a carne e outro com a salada de frutas e não podia trazer um terceiro. $\mathrm{O}$ meu eu tive que trazer dentro do saco. Então tem certas coisas que eu acho que..."

6.2 "Reviram tudo, não pode entrar quase nada, mas é bom, porque só assim evitam coisas ruins, mas o problema todo é amassar o biscoito, amassar o bolo, do jeito que eles pegam as coisas e amassam, parece que os filhos são cachorro, já vai chegando toda revirada, toda nojenta, muitas das vezes a comida até azeda, pelo tempo que espera, eu já estou esperando aqui há um tempão, pelo tempo a comida azeda, eu vou esquentar a comida."

A revista dos alimentos é também um momento de tensão para os visitantes, pois a comida é revirada sem o menor cuidado, o que é uma forma de exposição contaminadora, e a própria forma de acondicionamento, em sacos plásticos, informa aos visitantes que as mulheres presas, e eles mesmos, não são reconhecidos como pessoas merecedoras de dignidade e respeito. $\mathrm{O}$ injustificado tempo de espera para a entrada na unidade prisional também é uma queixa frequente, pois além de ser uma forma de comunicar o poder dos agentes sobre o tempo dos visitantes, pode fazer com que os alimentos levados para o almoço com a mulher encarcerada estraguem.

Ensina Goffman (1961) que, nas instituições totais, as mortificações do eu são oficialmente racionalizadas com variados fundamentos, como a segurança, no caso das prisões, mas que na verdade refletem o esforço de controlar a vida de um grande número de pessoas utilizando poucos recursos (GOFFMAN, 1961, p. 48). Aquilo que para os internados é considerado 
privilégio, em sua vida anterior era aceito como direito indiscutível. Logo, o autor ressalta que pode haver um constante conflito para a equipe dirigente, entre tentar manter padrões humanitários e garantir a eficiência da instituição (GOFFMAN, 1961, p. 73). Os próprios visitantes tecem críticas a essas regras criadas sob o discurso da segurança, mas que na realidade servem apenas para controlar e, em último caso, desestimular as visitas:

4.5 "Ele disse assim 'Quer saber de uma coisa? Você não vai visitar ela, perdeu sua carteirinha por seis meses'. Eu falei assim: 'Por que que eu não vou visitar ela, já entrei com essa roupa"; ele falou: 'Você não vai entrar, perdeu sua carteirinha por seis meses' [...]. E a maior dificuldade da família é quando chega aqui, são os agentes penitenciários, uma semana entra uma coisa, na semana seguinte você traz, já não entra, eles ficam demorando para colocar as pessoas pra dentro, eu acho uma covardia, pô, eu até sou uma pessoa nova e tal, mas tem senhoras que vêm com crianças desde seis, sete horas da manhã, e vêm de longe, vêm de Magé, Cabo Frio, Macaé, vêm de tudo quanto é lugar, e quando chega aqui falta com o respeito, o que desanima às vezes vim visitar são eles, parece que é o que eles querem.”

Comfort (2008) relata que a privação de conforto físico e informações básicas e a obrigação de seguir um regime impraticável e imprevisível revelam aos visitantes que estes são considerados pessoas de menor valor, gerando sentimentos de estigma, confusão e humilhação (COMFORT, 2008, p. 50). A autora explica que as formas de degradação travestidas de medidas de segurança institucional, como os longos e imprevisíveis períodos de espera e o monitoramento rigoroso da aparência e das posses, são aplicadas exclusivamente às pessoas que tem uma conexão pessoal com o prisioneiro, o que sugere a extensão do corpo do condenado ao corpo do visitante. Essas condições de negligência e indignidade não são uma necessidade burocrática, mas sim uma forma de comunicar uma punição, estendendo o castigo aos familiares (COMFORT, 2008, p. 61).

\section{OBRIGAÇÃO DE ADOTAR POSTURAS AVILTANTES}

Outra forma de mortificação do eu descrita por Goffman (1961) é a obrigação de o indivíduo adotar alguns movimentos e posturas que traduzem 
imagens inferiores de si e são consideradas aviltantes. Isso inclui não apenas o dever de manter o corpo em posição humilhante, mas também de dar respostas verbais degradantes, como no padrão de deferência obrigatória das instituições totais. Há a necessidade de apresentar atos verbais de deferência em sua interação social com a equipe diretora que, por sua vez, pode gozar dele, ou falar a seu respeito como se não estivesse presente (GOFFMAN, 1961, p. 30). Nesse sentido, o autor afirma que, na sociedade civil, quando um indivíduo precisa aceitar circunstâncias e ordens que ultrajam sua concepção do eu, ele tem certa margem de expressão para demonstrar uma reação, como o mau humor, exteriorizações fugidias de desprezo, ironia e sarcasmo, ou seja, a obediência está associada a uma atitude manifesta de contrariedade (GOFFMAN, 1961, p. 40). Em uma instituição total acontecem respostas assim, as quais significam uma autodefesa às exigências humilhantes, mas os internos podem ser castigados por essa atividade, considerada insolência.

Podemos observar esse tipo de mortificação do eu quando os familiares descrevem o processo de revista a que são submetidos, e a necessidade de aceitar qualquer tipo de desrespeito em silêncio, em razão do temor da punição - no caso, a apreensão da carteirinha de visitante, algo que o impediria de visitar a mulher presa e, portanto, de levar para ela os itens essenciais, como alimentos, medicamentos e materiais de higiene. Alguns mencionam até mesmo o medo de que a sua familiar presa seja punida por qualquer comportamento inapropriado que apresentem com os agentes penitenciários, diante da vulnerabilidade da pessoa encarcerada perante a administração da unidade prisional. Muitos relatam punições desproporcionais, por manifestações de descontentamento e respostas às manifestações irônicas dos agentes.

2.2 "Não tenho do que reclamar, não. Não sei se é porque... isso entra, isso não entra, eu já procuro não trazer aquilo que não entra, não pode vir de sapato, é chinelo, é chinelo, eu procuro manter a norma deles, não quero que tomem a carteirinha, nem que prejudique ela lá dentro. Não faço nada que venha a prejudicar ela lá dentro e eu ficar sem carteira, porque qualquer coisinha aí, eles tiram a carteira do visitante. Eu também já estou com uma idade que não é pra passar por isso, né? E não me peça pra trazer nada. Nada, nada, nada, nada. E bolsa eu fico de olho, hein. Muito difícil. Não. Vai direitinho. Nada de tirar a roupa, nada de abaixar. Antigamente, há uns anos atrás era assim, humilhante. Agora não, normal. Passa direitinho, acabou." 
2.6 "Tem dias que eles tão bem, tem dias que não estão. Isso entra, isso não entra, tem dia que isso entra, tem dia que não entra, tem dia que eles estão com raiva, tem dias que eles estão bem. Se alguém fez alguma coisa, tipo assim, foi todo mundo na van pro scanner, e você jogou alguma coisa, aí todo mundo paga, se você criticou alguém, eles tomam a carteirinha, qualquer coisa, o sutiã, elas não gostaram, aí você não pode mais vir com aquele sutiã, agora tem scanner, eles fazem você levantar a blusa, não pode mais, tem dia que mandam você arriar a calça, não pode mais.”

3.3 "Os DESIPE são muito ignorante, muito ignorante, às vezes a gente não sabe que não pode entrar com um casaco preto, alguma coisa assim, eu que sou nova aqui, eu não sou acostumada com essas coisas de presídio, aí o que que acontece, eu venho com uma roupa que não pode entrar, elas já tratam na ignorância, a comida que eles mexem como se fosse coisa de mendigo, coisa assim, lavagem, eles mexem com nojo, é uma ignorância que só, e sem contar que você tem que aturar, né, se não aturar eles pegam a sua carteirinha e devolve só quando quiser, entendeu, mas isso que é ruim de suportar aqui, a ignorância, e a demora, porque eles pegam a carteirinha 9 horas, quando dá 10 horas, quase 11 horas, eles chamam, isso que é uó pra suportar aqui, é a ignorância, porque eles são muito ignorantes."

Conforme relatado, os visitantes recebem um tratamento muito ríspido por parte dos agentes, mas evitam expressar qualquer manifestação de descontentamento. Têm medo de serem impossibilitados de encontrar o familiar a partir da retenção da carteira de visitante, ou até mesmo de que a pessoa presa sofra algum tipo de retaliação, devido a uma reclamação sua. Muitos indicam que são tratados pelos agentes como se presos fossem, e que precisam reafirmar sua situação como cidadãos livres com frequência:

1.1 "Isso mesmo que eu tava contando agora. Eu tenho um jeito de chamar todo mundo de meu anjo, de meu amor, relacionado assim, não só ao sexo em si. Relacionado a homem, mulher, é meu jeito carinhoso de tratar, e eles são grossos, eles não aceitam, entendeu? Eu assim, várias vezes, em várias situações, de eu chamar, deles gritarem comigo e eu falar que não sou presa, entendeu? Pra baixar o tom de voz, eu sempre lembro eles que eu não sou presa."

2.5 "Eu particularmente não tenho o que dizer, porque elas aqui eu não tenho o que dizer, nunca me maltrataram, nunca me magoaram. Agora na outra, lá no Sete, Deus me livre, era um inferno. As agentes mal-amadas, mal-educadas, estúpida, grossa, lá a gente passou per- 
rengue. A maior parte das mães, da família que está aqui, vieram de lá, e ninguém, ninguém, naquele lugar lá foi feliz. Porque elas tratam as pessoas como se a gente não existisse, fosse um lixo, como se a gente fosse bandida, como se as mães tivessem mandado as filhas fazer alguma coisa de errado. Então elas tratam a gente muitíssimo mal. [...] Na outra cadeia, eu entrava chorando e saía chorando daquele cadeia."

6.5 "Ó, tem alguns, não são todos, tem alguns que são complicados de lidar, porque acham que a pessoa está presa aí dentro, acham que você também tem culpa da pessoa estar aí, acham que você é a mesma coisa. Entendeu? Não quer saber se você, se já teve alguma coisa na família desse jeito, se já não teve, tratam você como se você fosse... não todos, né, mas a maioria trata você com diferença, né? Como se pobre tivesse que morrer, como se visita de preso tivesse que morrer junto também, entendeu? Eles não querem saber. Complicado.”

Desse modo, podemos verificar que algumas pessoas tentam estabelecer a distinção entre a sua posição de visitante e a mulher presa perante os agentes penitenciários, de forma a garantir o mínimo de respeito no momento da revista para a entrada na unidade prisional, embora essa tentativa de afirmação de sua subjetividade não constitua uma oposição eficaz à dominação material e simbólica que o sistema prisional lhes impõe (FERRECCIO, 2018 , p. 46). De modo geral, as pessoas agem com resignação, tentando se adaptar às exigências do sistema penitenciário, e algumas, inclusive, tentam justificar o tratamento destinado aos visitantes pelos agentes.

3.1 "Eu não tenho do que reclamar, porque é o seguinte, as pessoas reclamam de muita coisa. Aquele que reclama é o que faz coisa errada, se você fizer o certo, você não tem motivo de reclamar, até porque você vai ser respeitado. Quem faz o certo é respeitado. Por mais que tenha uma divergência ou não, isso é normal, tá dentro do sistema. Então eu não tenho do que reclamar, eles me tratam superbem, a gente fala assim, o meu uniforme é esse, eu entro, eu não dou dor-de-cabeça, eles me tratam superbem, sabem que não vão ter dor-de- cabeça comigo em relação a nada, eu entro com aquilo que é devido, aquilo que a regra... Tem uma regra. Não passo dessa regra, então eu não tenho do que reclamar."

3.4 "Bem, assim, eu não tenho nada do que reclamar, não, eles são meio grossos, né, isso aí é verdade, um pouquinho grossos, mas tranquilo, só é aquilo, você tem que respeitar, porque eles estão ali tra- 
balhando, eles estão ali trabalhando, fazer tudo o que eles falam, se não é pra trazer açúcar, você não traz, se não é pra você vir com uma roupa, você não vem, então eles estão ali fazendo o trabalho deles, você também tem que fazer o seu, porque trabalho é trabalho, mas eu não tenho do que reclamar deles, não, aqui eles são muito bons, não tenho do que reclamar deles não, graças a Deus."

Podemos observar que as incertezas relativas às diversas proibições e especificações dos alimentos e vestimentas permitidos gera atrito com os agentes penitenciários, que tratam os visitantes de forma grosseira diante de seu desconhecimento das regras de acesso ao sistema prisional. Tais regras não estão dispostas em lugar nenhum de forma precisa, e os visitantes devem tolerar esse tratamento desrespeitoso em silêncio, diante do temor das possíveis punições.

Assim, a exposição contaminadora na espera em um local sujo e inadequado às suas necessidades básicas, a sua desconfiguração pessoal diante da necessidade de usar um "uniforme" e a imposição do silêncio diante do tratamento desrespeitoso dos agentes devido ao temor de que a pessoa presa sofra retaliações constituem a experiência carcerária dos visitantes, marcada por diversas formas de mortificação do eu. Todas as dificuldades que os familiares precisam superar para realizar as visitas, bem como o tipo de abordagem a que são submetidos parecem ser um modo de estender-lhes a punição e, a partir da percepção dos entrevistados, desestimular as visitas.

\section{PRISIONIZAÇÃO SECUNDÁRIA}

Os efeitos para as pessoas afetadas por essas racionalizações que promovem diversas formas de mortificação do eu são avassaladores, ao ponto de os visitantes indicarem que se sentem presos também. Então, notamos que a pena efetivamente se estende à família, que sofre diversos danos colaterais do encarceramento, o que Comfort (2008) denomina de prisionização secundária, identificada como o processo pelo qual os familiares de encarcerados, devido ao seu contato com os entes queridos que estão presos, experimentam restrições de direitos, escassez de recursos, marginalização social e outras 
consequências do confinamento penal, mesmo que sejam legalmente inocentes e residam fora dos muros da prisão (COMFORT, 2008, p. 07). Segundo a autora, esse processo é derivado e dependente da prisionização primária de seus familiares (COMFORT, 2008, p. 15) e é relacionado às cerimônias de degradação que resultam em processos de mortificação do eu a que os visitantes são submetidos, os quais evidenciam seu status de quase-presos (COMFORT, 2008, p. 27).

As interações com a penitenciária transformam as rotinas diárias e a vida social dos visitantes, por meio do controle de sua aparência, de seu tempo, das suas relações (COMFORT, 2008, p. 14). A prisionização secundária implica uma profunda ambivalência, pois aquelas pessoas são simultaneamente livres e cativas (COMFORT, 2008, p. 16), o que faz com que a autora sustente que os visitantes constituem uma categoria peculiar de quase-presos: não estão condenados mas estão sob suspeita constante das autoridades, ainda que temporariamente, durante o período em que se encontram no presídio.

Embora essas interações ocorram principalmente nos limites entre a penitenciária e o mundo exterior, elas repercutem amplamente na vida dos familiares, pois essas pessoas devem ajustar seus horários, vestimentas e comportamentos para cumprir as exigências do sistema penitenciário e, assim, acabam ampliando as consequências da prisionização secundária para além dos muros (COMFORT, 2008, p. 16). Isso se dá ao ponto de os visitantes expressarem que também se sentem presos.

3.1 "Muda tudo. A vida muda, a história da vida. A história da vida muda porque você tem que parar de fazer muitas coisas para poder dar atenção a ela devida, ou seja, você passa a viver a vida de um preso, eu digo muito isso, quem ama fica preso juntinho. A gente não tem uma vida social, não tem uma vida mais normal, de segunda a sexta-feira trabalhando e sábado e domingo vindo pra Bangu, visitar." 6.2 "Bangu a gente não olha como presídio, a gente olha como uma residência, a gente só vai olhar isso lá dentro, porque ali que é o tratamento, nós temos que ver as nossas filhas aí dentro como se elas morassem aí, do mesmo jeito que elas moram aqui, nós também moramos, eu moro todas as semanas, tem pessoas que vêm uma vez por mês, tem umas de 15, outras que vêm de três em três meses, porque não pode tá vindo porque mora muito longe." 
6.3 "O efeito é devastador, desestrutura totalmente a família. Eu costumo falar que a gente sofre mais do que elas lá dentro, porque elas estão pagando pelo erro e a gente não fez nada, e a gente paga juntinho, estamos presas igual a elas, porque a gente não pode sair, não pode ir a lugar nenhum porque tem o compromisso de estar aqui. Fora isso, é a saudade que é muita e a gente tem que sobreviver, né? Bola pra frente que um dia acaba. Um dia acaba."

3.7 "Mas no caso, a gente é presa junto, a gente passa junto, acaba sendo presa junta, essas coisas que eu acho humilhante. E é assim, quando vai pro scanner, entra no carro pro scanner, tem que botar a mão pro alto, então, quer dizer, estamos presas também, porque tem regra, nós temos que colocar a mão pro alto, em cima da cadeira, quando chega lá, aí é um atrás do outro em fileira."

Assim, há uma extensão da pena para os familiares que visitam as mulheres presas, que precisam adaptar toda a sua vida ao cotidiano da unidade prisional, no esforço de fornecer o suporte material e emocional necessários para que elas enfrentem a situação de encarceramento. Ferreccio (2018, p. 52) indica que as mulheres, principais visitantes, têm sua vida atravessada por um processo de socialização carcerária no contato continuado e sistemático com o aparato burocrático das prisões. Cada visita constitui mais um episódio desse processo, que define não apenas suas condutas e percepções de aceitação e colaboração, mas principalmente a capacidade de desenvolverem sua subjetividade na prisão, como se estivessem detidas. Dessa maneira, a autora não pensa na experiência das visitantes como secundária ou proveniente daquela das pessoas presas, mas como uma vivência que se desenvolve de forma autônoma, paralelamente à de seus familiares encarcerados e com algumas intersecções, mas que cada ator é titular de sua própria experiência carcerária (FERRECCIO, 2018, p. 67).

Desse modo, os visitantes possuem uma experiência carcerária própria, derivada da prisionização secundária, que revela a ampliação dos efeitos do encarceramento no tecido social a partir das relações que familiares de pessoas presas estabelecem com o sistema prisional. No entanto, os visitantes não são os únicos afetados pelo encarceramento, os filhos das mulheres presas são atingidos de diversos modos por sua prisão, situação que se agrava, se considerarmos as dificuldades adicionais da entrada de uma criança no sistema 
penitenciário, o que em muitos casos inviabiliza sua presença no local. Tais fatores serão analisados a seguir.

\section{EFEITOS PARA AS CRIANÇAS}

Não há dados precisos sobre a quantidade de crianças afetadas pelo encarceramento de seus familiares, principalmente genitores, mas o último Levantamento Nacional de Informações Penitenciárias informou que 74\% das mulheres presas possuem filhos (DEPEN, 2018, p. 51), ressalvando a baixa representatividade da amostra coletada, visto que a maioria dos estados não dispõe dessas informações, inclusive o Rio de Janeiro, local em que foi realizada a pesquisa. Isso demonstra a invisibilidade das crianças e de sua situação nos registros oficiais, contrariando as previsões das Regras de Bangkok ${ }^{2}$, o que ressalta um abandono inescusável por parte do poder público: se elas não foram sequer identificadas, como garantir que estejam vivendo em condições dignas, que não estejam abandonadas após o encarceramento de seus responsáveis?

Isso não ocorre apenas no Brasil, e Codd (2011, p. 62) afirma que a ausência de dados mais precisos sobre as crianças afetadas pelo encarceramento dos genitores é consequência da invisibilidade da família das pessoas presas nos registros oficiais. Tal fato é problemático, principalmente diante do constante crescimento da população prisional, em especial a feminina, o que amplia também o número de crianças e jovens atingidos. A autora salienta que o encarceramento da mãe é particularmente severo para as crianças, pois em muitos casos as mães representam a única "âncora" dos filhos, os quais ficam “à deriva” com a sua prisão (CODD, 2011, p. 63).

Um dos fatores relatados pelos visitantes que dificultam o convívio das crianças com a mãe presa é a distância entre o local de residência e a penitenciária. No Rio de Janeiro, as unidades prisionais femininas de regime fechado

\footnotetext{
BRASIL. Conselho Nacional de Justiça. Regras de Bangkok. Regras das Nações Unidas para o tratamento de mulheres presas e medidas não privativas de liberdade para mulheres infratoras. Brasília, 2016. Disponível em: http://www.cnj.jus.br/files/conteudo/arquivo/2016/03/a858777191da58180724ad5caafa6086.pdf. Acesso em: 01 set. 2018.
} 
são concentradas no Complexo de Gericinó e arredores, em Bangu, com a ressalva do Presídio Nilza da Silva Santos, em Campos. Então, há todo um desgaste e um custo relacionado ao transporte para a visitação, muitas vezes em outra cidade, que seriam ainda maiores com a presença da criança. Além disso, um contratempo sempre mencionado é a necessidade de ter a guarda legal da criança e, a partir dos sete anos, a indispensabilidade de confeccionar sua carteirinha de visitante para que consiga autorização para entrar no presídio, o que muitos evitam por temer "sujar" o nome dos pequenos com o registro de visitante de pessoa presa. As crianças que não possuem carteirinha precisam de autorização específica para ver suas familiares, em horários diferenciados e eventos especiais, como Dia das Mães e Dia das Crianças, em que há uma autorização mais abrangente.

1.2 "Às vezes eu trago [os netos para ver a mãe deles], mas raramente. Não gosto muito de trazer eles pra cá, não. É muito cansativo pra gente, quanto mais pra criança. O outrozinho, a hora que eu quiser trazer, eu trago, porque eu tenho a guarda definitiva dele, aí eu trago, agora, a outra, tem que pegar autorização. Aí eu peço a ela pra pegar a autorização, ela pega e eu trago. Eu trago às vezes. Até ele falou: 'Vó, me leva pra eu poder ver minha mãe?' Aí eu falei assim: 'Tá, vou levar'. Eu fico com pena de acordar o bichinho de madrugada. E ele estuda de manhã, ele estuda 7 horas, mas aí, poxa, 7 horas, seis e pouco ele levanta, toma o cafezinho dele, se arruma, aí a rota vem pegar ele. Mas, poxa, eu levanto 4 horas. 4 horas já tô me arrumando, já tô na frente do portão esperando o ônibus. Então é mais cansativo ainda. É... Ele tem quatro anos. E ele enjoa. E outra coisa, um frio danado, acordar o bichinho 4 horas da manhã, não, fica dormindo. É, fica dormindo... Vai dormir. E é cansativo. Eu saio daqui, parece que eu limpei mais de não sei quantas casas, menina. É. Pode perguntar pra todo mundo aqui, quando sai daqui. Parece que um trator passou em cima da gente. A gente fica morta quando sai da visita. Imagine trazer criança pra cá? Ah, eu não gosto, não. Sinceramente. Falo: 'Quer ver seus filhos, fica lá na rua."”

1.7 “Criança só pode entrar até sete anos sem carteirinha, com a certidão de nascimento, a guarda, porque ela tem que passar a guarda pra alguém aqui fora, aí ela passou pra minha mãe. A guarda dos dois mais velhos, era os que vinha, só que a mais velha fez 11, fez 12, tem uns quatro ou cinco anos que ela não vem mais, e o segundo mais velho também, ele fez oito já, aí já tem um ano e pouco que ele não vem. Então eles só vêm só quando tem uma festa, tipo Dia das Mães, 
ela consegue pedir autorização pra eles entrarem. Minha mãe tem a guarda deles, vem com a guarda, a documentação da minha mãe, das crianças, como é filho da interna e dá entrada em tudo, é quando eles conseguem vim. São umas quatro festas por ano."

3.4 "A filha dela ainda não vem visitar porque tem que pegar autorização do juiz, pra vir, como é muita burocracia, muito trabalho, minha mãe achou melhor ela não vim, aí ela vem assim Dia das Mães, Dia das Mães eles autorizam aqui, aí pode trazer. Mas a gente não achou bom trazer, não, porque ela fica muito traumatizada. Quando ela sai, ela chora muito. Só de vez em quando, mesmo."

6.1 "Onde já se viu uma menina de 13 anos fazer carteirinha e sujar o próprio nome? Vai querer fazer um concurso público, não vai poder fazer. Aí eu vou ter que fazer o quê? Entrar em recesso com a Justiça pra minha filha poder fazer. Isso não existe. O filho dela tem 11 anos, não pode visitar a mãe. Tem que fazer carteirinha."

O convívio das crianças com a mãe presa é prejudicado por vários motivos, alguns burocráticos, como a necessidade de que o visitante obtenha a guarda legal da criança ou da confecção de sua carteirinha de visitante, a partir dos sete anos, além de outras questões de ordem logística, como a distância, o custo do transporte e o desgaste físico de levar os pequenos até a unidade prisional nos dias e horários determinados. Os efeitos do encarceramento para crianças, principalmente para os filhos da mulher presa, relatados pelos visitantes, incluem depressão, rebeldia, isolamento e obesidade. Influenciam, inclusive, a estrutura cognitiva daquelas, a partir da separação repentina da pessoa que lhes dedicava cuidados integralmente.

1.6 "Meus netos não é criado comigo. Vejo. A filha dela teve aquela... Como é que eu vou te dizer, ela teve depressão, mas a depressão dela foi dela pegar obesidade. Tá gorda, tá, sabe? Mas é a falta da mãe. Ela agride as pessoas com palavras, mas porque ela quer a mãe dela. Eu quero a minha. Eu, que tô com 42 anos, eu vivo perto da minha. Imagine ela, uma criança."

2.5 "É doído, porque é uma situação que a gente não desejaria para ninguém. As crianças, o menino dela está com 12 anos hoje, tá sendo assistido por psicólogo, porque está revoltado, por mais que eu dê, porque graças a Deus não está faltando nada, mas tem a falta da mãe, e essa idade já é complicada tando tudo bem, agora imagine você sem a mãe por perto." 
5.4 "Muito difícil, notei, poxa, muito difícil, pegava ela chorando às vezes quietinha, alguns meses chorando assim quietinha... 'Filha, por que você está assim, não sei o que, chorando', eu procurava distrair ela [...]. O pior de tudo eu acho que é a solidão, que minha filha fica longe dela, eu também, mas a dela é maior, o pior de tudo é a solidão dela, pior de tudo, ela tá sempre fazendo pergunta pra mim, entendeu, pode crer que é isso mesmo, o pior de tudo é ver o sofrimento da minha filha.

5.5 "Igual meu irmão, não quer ir pra escola, tá meio abusado, tem toda aquela rebeldia de adolescente, mas coisas que dá pra relevar, mas realmente ele sente muita falta dela, porque ele era muito agarrado com a minha mãe, aonde ela tava, ele tava, e ela sofre muito com isso, eu trago fotos pra ela, eu trago fotos dele recente pra ela poder ver, e tudo o mais, e a gente vai matando a saudade da forma que dá, então eu acho que o pior castigo pra elas, além de serem privadas da liberdade, é não ter contato com quem mais ama, com a família, que é o que ajuda, então isso eu acho que é o pior castigo pra elas."

6.2 "A minha neta, a filha dela, eu percebo que ela tem um problema assim, que tem que levar no... que o psicológico dela, ela tá com o aprendizado bem abalado, por ela estar com nove anos agora e ainda não aprendeu a ler, né, e escrever, ela escreve bem pouco, escreve cartinha pra mamãe, mas é aquilo, tudo embolado, não tem muita... desenvolvimento, eu creio que foi assim, alguma coisa que mexeu na cabeça dela, o psicológico, a cabecinha dela não entra muito, né?"

5.8 "A saudade, porque tem crianças de cinco anos, gêmeas, precisando da mãe, e tá o pai e a mãe presos. A avó cuida de todos, e as crianças estão sofrendo muito. Tem a de 15 anos, que fez 15 semana passada, está depressiva, agora que ela aceitou psicólogo. Aí ela vai começar, porque ela está sequinha, não come. As crianças pedem pela mãe o tempo todo, e tá difícil."

Desse modo, as crianças são afetadas diretamente pelo encarceramento de suas mães, que produz alterações profundas em seu cotidiano e diversas consequências físicas, psicológicas e emocionais, as quais são ignoradas nas análises sobre os efeitos das políticas de segurança pública. Braman (2002) relata que, em sua pesquisa, diversas famílias descreveram os efeitos negativos do encarceramento no comportamento e no rendimento escolar das crianças (BRAMAN, 2002, p. 124). O autor ressalta que crianças com genitores presos estão mais vulneráveis a abusos sexuais e à pobreza, e mais suscetíveis ao envolvimento com o sistema de justiça criminal, contribuindo para um ciclo de abuso e negligência que perpassa gerações (BRAMAN, 2002, p. 127). 
A situação é ainda mais complexa quando a mãe é presa, ocasião em que as crianças são especialmente afetadas, visto que as mulheres, que ainda são as principais responsáveis pelo cuidado, são excluídas do convívio familiar. Isso causa grandes transformações na vida cotidiana de seus filhos que, em muitos casos, têm que mudar de residência, ficando sob a guarda de avós ou outras mulheres da família, podendo ser separados dos irmãos entre familiares de núcleos diversos, ou até mesmo sendo afastados do convívio familiar, passando a uma situação de abrigamento.

Assim, as crianças são as principais afetadas pelo encarceramento da mãe, ainda que não tenham contato frequente com o sistema prisional após tal prisão, e até mesmo devido a essa escassa comunicação. São diversos os fatores que impedem uma convivência efetiva entre mãe e filhos quando aquela se encontra presa, e esse afastamento brusco promove consequências incalculáveis na vida dessas crianças.

\section{CONCLUSÃO}

Em nossa pesquisa com os visitantes da Penitenciária Talavera Bruce pudemos observar como o encarceramento gera impactos na família de mulheres presas por meio da prisionização secundária, seja com o compartilhamento do estigma relacionado à prisão, que afeta suas relações sociais, principalmente pelo isolamento e necessidade de encobrimento, seja com as diversas formas de mortificação do eu a que tais pessoas são submetidas no momento da entrada no ambiente prisional, envolvendo a observância de um código de vestimenta muito restrito, ao ponto de indicarem possuir um "uniforme" para realizar a visitação, a imposição de esperas longas e sem informações em um local coberto de lixo e a humilhação de acondicionar comida em sacos plásticos e vê-la ser revirada durante a revista, além das memórias de revistas íntimas vexatórias.

Ademais, destaca-se a instabilidade durante o procedimento de revista para a entrada no ambiente prisional, diante de regras sobre vestimentas e materiais que podem ser deixados para as presas. Essas diretrizes frequentemente são alteradas, e de forma imprevisível, além de serem aplicadas de 
forma irregular pelos agentes penitenciários, o que gera confusão e sensação de impotência nos familiares. Além disso, estes precisam suportar em silêncio todo tipo de desrespeito por parte dos agentes penitenciários, sob a constante ameaça de apreensão da carteira de visitante, o que inviabilizaria não só os encontros em si, mas a entrega de gêneros alimentícios, remédios e material de higiene para a presa. Também há o temor de que a pessoa encarcerada seja punida pelo comportamento de seus visitantes. Dessa forma, podemos compreender como a punição é estendida aos familiares, que representam para o aparato repressivo uma continuação do corpo do condenado.

Assim, os relatos dos familiares que visitam as mulheres presas expõem as mazelas da utilização massiva do encarceramento como controle social dos indesejáveis na nossa sociedade, cujos desdobramentos se estendem muito além da pessoa efetivamente encarcerada, por meio da prisionização secundária, contrariando o princípio da intranscendência da pena. No caso das mulheres, temos ainda o agravante das consequências de seu encarceramento para os filhos, visto que as mães ainda são as principais responsáveis pelo cuidado. Com a prisão, as mulheres são subitamente afastadas de suas crianças e têm seu convívio com elas dificultado, tanto pela distância quanto pelas exigências burocráticas para a visitação.

Nesta pesquisa buscou-se investigar os efeitos do encarceramento para a família das mulheres presas, de modo a evidenciar as consequências ocultas do encarceramento em massa para a sociedade. Conhecendo as realidades que a prisão produz, questionamos a sua utilização, posto que tem se mostrado ineficaz aos seus objetivos declarados, e produz efeitos nocivos imensuráveis e que são desconsiderados quando da decisão de encarceramento, e que alcançam muito além das pessoas que se encontram efetivamente atrás das grades.

\section{REFERÊNCIAS BIBLIOGRÁFICAS}

1. BRAMAN, Donald. Families and incarceration. In: MAUER, Marc; CHESNEYLIND, Meda. Invisible punishment: the collateral consequences of mass imprisonment. New York: The New Press, 2002. 
2. BRASIL. Ministério da Justiça. Departamento Penitenciário Nacional. Levantamento Nacional de Informações Penitenciárias - INFOPEN Mulheres 2016. 2. ed. Brasília, maio de 2018. Disponível em: http://depen.gov.br/DEPEN/ depen/sisdepen/infopen-mulheres/infopenmulheres_arte_07-03-18.pdf. Acesso em: 31 ago. 2018.

3. BRASIL. Conselho Nacional de Justiça. Regras de Bangkok. Regras das Nações Unidas para o tratamento de mulheres presas e medidas não privativas de liberdade para mulheres infratoras. Brasília, 2016. Disponível em: http://www.cnj. jus.br/files/conteudo/arquivo/2016/03/a858777191da58180724ad5caafa6086. pdf. Acesso em: 01 set. 2018.

4. CODD, Helen. In the shadow of prison: families, imprisonment and criminal justice. New York: Routledge, 2011. Second Edition.

5. COMFORT, Megan. Doing time together: love and family in the shadow of the prison. Chicago: The University of Chicago Press, 2008.

6. FERRECCIO, Vanina. El otro encarcelamiento femenino: la experiencia carcelaria de las mujeres familiares de detenidos. Revista Crítica Penal y Poder, Barcelona, $\mathrm{n}^{\circ} 15$, p. 43-70, octubre 2018.

7. GOFFMAN, Erving. Estigma: notas sobre a manipulação da identidade deteriorada. Tradução: Mathias Lambert. 4.ed. Rio de Janeiro: LTC, 1981.

8. GOFFMAN, Erving. Manicômios, prisões e conventos. São Paulo: Editora Perspectiva, 1961.

9. PETRUCCELli, José Luiz; SABOIA, Ana Lúcia. (Orgs.). Classificações e identidades. Características étnico-raciais da população. Rio de Janeiro: IBGE, 2013. (Série Estudos e Análises. Informação demográfica e socioeconômica, n. 2).

10. ZAFFARONI, Eugenio Raúl; PIERANGELI, José Henrique. Manual de Direito Penal Brasileiro: parte geral. 9. ed. rev. e atual. São Paulo: Editora Revista dos Tribunais, 2011. v.1.

Recebido em 01 de setembro de 2018

Avaliador A: 18 de outubro de 2018

Avaliador B: 27 de novembro de 2018

Aceito em 27 de novembro de 2018 